\title{
The Inter-Firm Value Effect in the Qatar Stock Market: 2005-2014
}

\author{
Omar Gharaibeh ${ }^{1}$ \\ ${ }^{1} \mathrm{Al}$ albayt University, Jordan \\ Correspondence: Omar Gharaibeh, Al albayt University, Jordan. E-mail: omar_k_gharaibeh@yahoo.com
}

Received: June 30, 2015

Accepted: July 13, 2015

Online Published: December 18, 2015

doi:10.5539/ijbm.v11n1p189

URL: http://dx.doi.org/10.5539/ijbm.v11n1p189

\begin{abstract}
This paper examines whether there is evidence of an inter-firm value in the returns of Qatar firms. The long-term return contrarian and book-to-market strategies are approaches commonly used to test for value effect. This study documents statistically significant abnormal profits of an inter-firm value effect with two measures. The long-term return contrarian and BE/ME strategies provide significant abnormal raw returns of $1.17 \%$ and $1.64 \%$ per month, respectively. Although each of the value strategies earns significant unadjusted profits, these profits can be explained by the Fama-French three-factor model.
\end{abstract}

Keywords: Qatar Stock Exchange (QSE), contrarian, three-factor model

\section{Introduction}

In an important paper, Asness, Moskowitz and Pedersen (2013) study value (and momentum) strategy returns for global stocks, equity indices, currencies, government bonds and commodities. They find evidence of value and momentum effects in each asset class. Other studies have produced mixed evidence regarding the existence of an inter-industry value effect. Chou, Ho, and Ko (2012) state that the book-to-market effect in the U.S. equity market is basically an intra-industry phenomenon. In this paper, the question of whether there is a value effect across Qatar firms.

This study conducts investigation using two alternative measures for determining value. The first value measure is the firm's book-to market (BE/ME) ratio: as for stocks, firms with high BM ratios are regarded as 'value' while those with low BM ratios are regarded as 'growth'. Following the approach used by Asness et al. (2013) to determine value for currencies and bonds, the second measure (contrarian) is based on long-term past returns. Value firms are those with poor long-term past returns whereas growth firms have high long-term past returns. Following the previous studies, this paper similarly uses 36, 48 and 60-month when applying the long-term past returns.

In this paper we consider whether there is a value effect at the level of Qatar stock market. Although the predictability of stock returns are broadly examined in developed stock markets, the emerging market, especially gulf countries are not investigated, therefore, Qatar remains awaiting such investigations. The main finding provided in this paper is that there is strong evidence of an inter-firm value effect in the Qatar equity market consistent across the two value measures. Although each of the value strategies earns significant unadjusted profits, these profits can be explained by the Fama-French three-factor model.

The reminder of this paper is organized as follows. The next section discusses the literature review for the value effect. Section 3 describes the data and portfolio formation used in this paper. Section 4 presents the main empirical results. A summary and conclusion are in Section 5.

\section{Literature Review}

The value effect, originally described by Stattman (1980) that reports a positive relationship between book-to-market ratios and subsequent abnormal returns. Firms with high book-to-market ratios produce average returns that are higher than can be justified by the CAPM, and firms with low book-to-market ratios produce average returns that are lower than can be justified by the CAPM. This effect is known as the book-to-market effect or value anomaly.

A landmark paper on both the value and the size effect is Fama and French (1992). Fama and French (1992) undertook a comprehensive study of the impact of these two effects on the CAPM and came to the conclusion that the CAPM is misspecified. DeBondt and Thaler (1985), Fama and French (1992) and Lakonishok, Shleifer 
and Vishny (1994) provided evidence that stocks with high BE/ME ratios have higher average returns than growth stocks, which have low BE/ME ratios. More recently, Zhang (2008) showed that the book-to-market effect has strengthened in recent years, while Fama and French (2008) report that the book-to-market effect is present in many international markets.

The three-factor model of Fama and French (1993) has attracted the attention of many academic researchers and practitioners, as it showed that the CAPM does not provide an adequate explanation of realized returns. Using Fama and French's (1993) procedure to construct risk factors, Simlai (2009) re-examined whether the size and book-to-market factors are related to the performance of portfolio returns. Simlai (2009) showed that the size and book-to-market ratios play an important role in explaining the variation in stock returns over the period from July 1926 to June 2007. Simlai (2009) found that the common risk factors' effect in interpreting the time series variation in the size and book-to-market sorted portfolios, can be substantially improved by volatility persistence.

Lakonishok et al. (1994) (LSV) investigated the relative performance of value strategies and found that they outperform the market. In their study, the information on past growth in cash flow, sales and earnings was used to measure past performance, while multiples of price to current earnings and cash flow were used to measure expected performance. Their finding supported the result of Fama and French (1992) that value strategies provide high returns but they provided a different reason. Whilst Fama and French (1992) sought to explain the profitability of value strategies by arguing that these strategies were fundamentally riskier, Lakonishok et al. (1994) regard their profitability as being the result of stock mispricings by other investors.

Investigating portfolio returns in the Australian stock market, Kassimatis (2008) analysed whether firm size, book-to-market and momentum risk factors have an explanatory effect. The CAPM and four-factor model were compared to show that size, book-to-market and momentum factors have significant explanatory power when taking into consideration the time variation in factor loading. Kassimatis (2008) proposed that additional factors may proxy for misspecified market risk. He showed that realized returns can be significantly explained by the return of SMB, HML and WML (winners minus losers) arbitrage portfolios. The study provided clear evidence that the CAPM estimated based on static OLS is not sufficient to explain expected returns because beta is assumed to be constant during the period investigated.

Chen (2011) examined the reason why the book-to-market effect increased in small stocks and decreased in large stocks. A fully rational model was built to explain the heterogeneity of the book-to-market effect. The main prediction of the model was that BM plays a stronger role in stocks with short life expectancy. Using the delisting probability as a proxy for the firm's life expectancy, the model's central prediction and its additional implications for stock return and variance have been supported by the data. His analysis found that firms with short life expectations have high idiosyncratic volatility.

Dempsey (2010) has examined the role of the BM ratio in the formation of stock returns. He investigated whether the BM ratio should be considered a "risk-based", and not a "mispricing" explanation for share prices in the Australian markets. This research was motivated by the explanation of stock return performance suggested by the Fama and French three-factor model, and used Peterkort and Nielsen's (2005) approach to explain the relationship between the BM variable and stock return. By constructing a sequence of diagnostic tests to distinguish between risk-based and mispricing based, the study confirms the previous results that stock returns are strongly related to the firm's book-to-market equity ratio. In addition, strong evidence suggests that this relationship stems from the BM ratio's absorption of the implication of company leverage as a risk factor. In spite of the distinctive characteristics of the Australian stock market, these results are substantially consistent with the U.S. results of Fama and French (1993) and Peterkort and Nielsen (2005).

In recent study, Chou, Ko, and Lin (2010) used several tests to investigate the competing explanatory power of Fama and French's (1993) three-factor model and Ferguson and Shockley's (2003) CAPM-based model in interpreting the existing anomalies. Brennan, Chordia and Subrahmanyam's (1998) methodology was used to evaluate the performance of the competing asset-pricing model. Brennan, Chordia and Subrahmanyam (1998) showed that the explanatory power of several company characteristics is still significant even after using Fama and French's (1993) three-factor model and Ferguson and Shockley's (2003) model. Specifically, they showed that the book-to-market premium remains considerably significant concluding that model fully capture the BM anomaly. On the other hand, Chou, Ko and Lin (2010) showed that most asset-pricing anomalies including BM can be explained by a simple conditional version of the augmented five-factor model, confirming the result of Brennan, Chordia and Subrahmanyam (1998).

The value strategies performed at industry level in this study will support or reject the existing research on the 
value effect. Considering the lack of research on the value strategy at firm level in the Qatar stock market, this paper will add to the body of research in the area of return predictability. This research will investigate the use of a number of alternative measures to determine value.

\section{Data and Methodology}

\subsection{Data and Sample Selection}

Monthly stock price covering the period of January 2005 to April 2014 had been obtained from Datastream. The sample of this study includes all 40 Qatar firms that have been listed in Qatar stock exchange. The study uses monthly returns, firm size (ME), and the firm book-to-market ratio (BE/ME) for 40 Qatar firms. For the market index, the study uses the monthly returns of the Qatar Stock Exchange (QSE) market of Morgan Stanley Capital International (MSCI) downloaded from Datastream. The study starts from January 2005 since the Datastream is a less comprehensive coverage of QSE stock prior to January 2005. The sample is collected of 112 monthly returns on each firm, on the market index, together with observations on the firm size and firm book-to-market ratio.

\subsection{Portfolio Formations}

This paper uses two alternative measures to determine value for each firm: the firm's BE/ME ratio as well as its 36, 48 and 60-month past returns. To test whether inter-firm value exists, DeBondt and Thaler's (1985) and Fama and French's (1993) methods have been employed. The stock returns are sorted in an ascending order based on both their past $J$-month formation period returns for $J=36,48$, and 60 months (for the contrarian strategy) and on their past BE/ME ratios (for the value strategy). Based on sorting, four equal-size portfolios are constructed. The first portfolio includes the $25 \%$ of firms with the lowest stock returns is the long winner and low BE/ME (denoted LW and LV, respectively), whereas the fourth portfolio includes the $25 \%$ of firms with the highest return is the long loser and high BE/ME (denoted LL and HV, respectively).

The zero cost contrarian strategy (LL-LW) is long the long-time loser portfolio and sells the long-time winner portfolio. The zero cost BE/ME strategy (HV-LV) is buying the high BE/ME portfolio and selling the low $\mathrm{BE} / \mathrm{ME}$ portfolio. Portfolios uphold for $K$-month holding periods, where $K=1,3,6,9$ and 12-month.

This study maintains a 1 year gap between the ending of the $J$-month formation period and the beginning of the $K$-month holding period for this particular strategy and this procedure is consistent with the Fama and French's (1996) approach and recent contrarian studies. Fama and French (1996) shows that exclusion the first year following the end of the formation period generates stronger reversal findings since this procedure assists evade long-time contrarian being compensated by the short-time reversal of returns. DeBondt and Thaler (1985) documents that the first 12 months of their holding period did not provide considerable reversal profits.

Table 1 reports firm summary statistics over the period January 2005 to April 2014 for the 40 Qatar firms, showing the monthly average return, standard deviation, value weighted book-to-market ratio, average firm size, and the skewness and kurtosis for each industry. There is a large variation in the mean and standard deviation of returns. Gulf international services, Gulf warehousing, Industries Qatar, Salam international investment, Medicare group and Qatar national bank holding have the largest monthly averages (over $2 \%$ per month), while Aamal has the lowest average at -1.29 . The 40 Qatar firms have an average monthly return of $1.08 \%$ and an average standard deviation of $12.17 \%$. 
Table 1. Descriptive statistics

\begin{tabular}{|c|c|c|c|c|c|c|}
\hline Firm Names & Average & SD & $\mathrm{BE} / \mathrm{ME}$ & ME (\$M) & Skew & Kurt \\
\hline Gulf international services & 2.53 & 10.50 & 0.59 & 4713 & 0.47 & 1.96 \\
\hline Gulf warehousing & 2.36 & 16.19 & 0.51 & 944 & 1.68 & 8.48 \\
\hline Industries Qatar & 2.31 & 15.23 & 0.30 & 71179 & 1.99 & 9.70 \\
\hline Salam international investment & 2.18 & 20.18 & 1.15 & 1328 & 3.22 & 16.84 \\
\hline Medicare group & 2.18 & 15.07 & 1.24 & 614 & 1.27 & 5.26 \\
\hline Qatar national bank & 2.13 & 11.21 & 0.42 & 60140 & 1.02 & 7.13 \\
\hline United development & 1.90 & 16.38 & 1.10 & 4579 & 2.13 & 12.36 \\
\hline National leasing holding & 1.73 & 16.34 & 0.65 & 1105 & 0.78 & 2.18 \\
\hline Zad holding company & 1.71 & 10.66 & 1.70 & 525 & 1.04 & 2.87 \\
\hline Mazaya Qatar reit & 1.60 & 8.26 & 1.11 & 1034 & 1.39 & 2.25 \\
\hline Qatar elty.\& wt. & 1.57 & 10.09 & 0.35 & 11176 & 1.51 & 10.14 \\
\hline Barwa real estate & 1.50 & 14.42 & 0.81 & 10322 & 0.70 & 3.62 \\
\hline Ezdan real estate & 1.44 & 19.08 & 0.60 & 49905 & 2.59 & 9.30 \\
\hline Qatar international Islamic bank & 1.43 & 11.03 & 0.46 & 7656 & 0.04 & 2.34 \\
\hline Qatari investors & 1.42 & 12.40 & 0.75 & 2335 & 1.06 & 4.59 \\
\hline Qatar Islamic bank & 1.38 & 12.88 & 0.46 & 17622 & 0.76 & 1.52 \\
\hline Ahli bank & 1.29 & 11.50 & 0.48 & 4496 & 1.34 & 6.78 \\
\hline Commercial broker of Qatar & 1.23 & 12.63 & 0.63 & 18016 & 0.07 & 0.89 \\
\hline Qatar Islamic insurance & 1.20 & 15.56 & 0.32 & 974 & 2.00 & 10.64 \\
\hline Masraf al rayan & 1.16 & 9.06 & 0.52 & 15572 & -0.58 & 4.42 \\
\hline Doha bank & 1.12 & 11.92 & 0.53 & 11892 & 0.39 & 0.60 \\
\hline Mannai corporation & 1.12 & 6.80 & 0.42 & 2897 & 0.88 & 2.00 \\
\hline Islamic holding & 1.09 & 15.94 & 0.33 & 141 & 2.55 & 12.10 \\
\hline Qatar insurance & 1.04 & 10.87 & 0.44 & 5956 & 0.05 & 2.16 \\
\hline Qatar navigation & 0.97 & 11.12 & 1.14 & 7103 & 0.43 & 1.90 \\
\hline Qatar cinema \& film ds. & 0.95 & 13.04 & 0.58 & 183 & 1.80 & 6.21 \\
\hline Alkhaleej takaful group & 0.86 & 14.48 & 0.55 & 739 & 0.47 & 2.56 \\
\hline Qatar qsc & 0.63 & 7.48 & 0.67 & 27034 & 0.26 & 0.27 \\
\hline Doha insurance & 0.59 & 11.90 & 0.60 & 602 & 0.81 & 5.15 \\
\hline Vodafone Qatar & 0.51 & 6.38 & 0.92 & 7333 & 0.68 & 3.44 \\
\hline Qatar general in.\& rein. & 0.49 & 11.94 & 0.66 & 1970 & 0.49 & 4.65 \\
\hline Qatari grm.for med.devc. & 0.46 & 12.66 & 1.29 & 136 & 0.78 & 4.17 \\
\hline Qatar national cement & 0.45 & 10.40 & 0.46 & 4550 & 1.79 & 7.48 \\
\hline Al khalij commercial bank & 0.39 & 9.69 & 0.84 & 6447 & 0.50 & 4.02 \\
\hline Qatar company for meat \& live. Trading & 0.28 & 10.79 & 0.54 & 532 & 1.09 & 2.72 \\
\hline Qatar industrial manufacturing & 0.13 & 6.45 & 0.65 & 1701 & -0.10 & 0.84 \\
\hline Qatar Oman investment & -0.02 & 9.84 & 1.05 & 329 & 0.56 & 4.05 \\
\hline Dlala brokerage \& investment holding & -0.42 & 16.08 & 0.49 & 610 & 1.70 & 6.64 \\
\hline Qatar gs.tran.nakilat & -0.52 & 10.38 & 0.25 & 12806 & 1.04 & 3.51 \\
\hline Aamal & -1.29 & 9.99 & 0.63 & 9977 & -1.08 & 5.45 \\
\hline Average & 1.08 & 12.17 & 0.68 & 9679 & 0.99 & 5.08 \\
\hline
\end{tabular}

This table provides the descriptive statistics for 40 firm returns from January 2005 until April 2014, obtained from Datastream. The first column is the name of the firm. This is followed by the average monthly returns, the standard deviation of monthly returns, book-to-market ratios, capitalization, the "Skew" is the skewness, and the "Kurt" is the kurtosis for each firm.

\section{Analysis of Results}

Section 4.1 presents the findings of the value strategies based on long-term contrarian and book-to-market equity ratio for Qatar stock market. Section 4.2 provides the post holding results for the same strategise. Section 4.3 shows the risk-adjustment regression. 


\subsection{Value Results}

Table 2. Profitability of long-term contrarian at Qatar firms

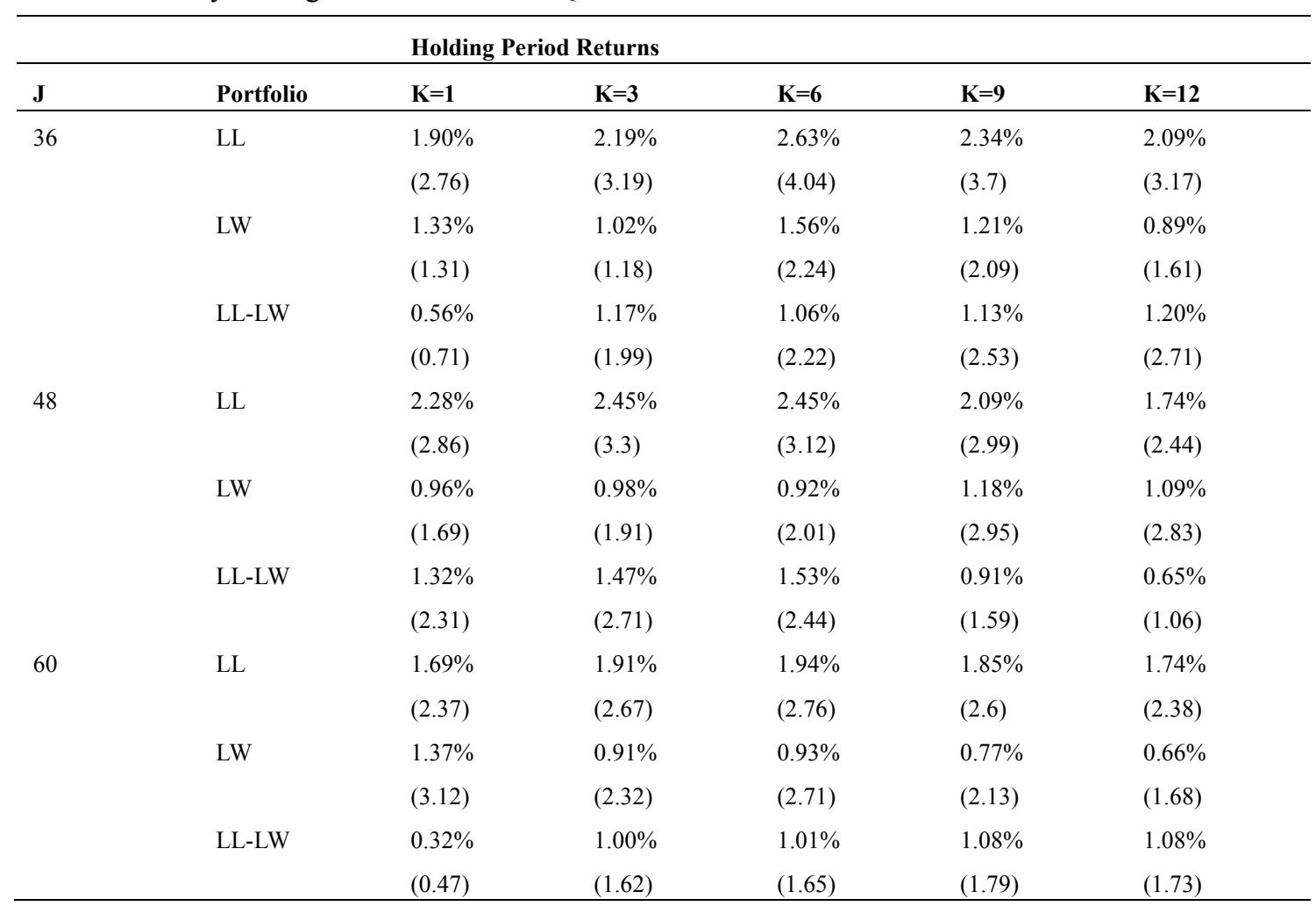

Table 2 provides the average monthly holding period returns in percentages of the selling, buying, and selling minus buying portfolios of the long-term reversal strategy for 40 Qatar firms. Portfolios are constructed as follows: At the beginning of each month $\mathrm{t}$, the 40 firms are sorted derived from their past $J$-month formation period returns for $J=36,48$, and 60 months. The long-run loser equal-weighted portfolio (LL) comprises of the $25 \%$ of portfolios with the lowest returns, and the long-term winner equal weighted portfolio (LW) comprises of the $25 \%$ of portfolios with the largest returns. The strategy LL-LW buying the long-run loser portfolio and sells the long-run winner portfolio to be held for $K=1,3,6,9$, or 12 months. The $t$-statistics depends on the Newey and West (1987) adjustment for autocorrelation up to lag 11.

Table 2 reports result for the short (LW), long (LL), and long-short (LL-LW) long-term contrarian portfolios for various $(J, K)$ combinations. Table 2 involves the results for formation period lengths of $J=36$, 48, and 60 months. This Table provides the equal-weighted average monthly portfolio returns in percentages for $K$-month holding periods ( $K=1,3,6,9$ and 12 months) in columns 3 through 7 .

Except for the $J=60$ case in Table 2, which provides weakly significant profits for most $K$, the long-term return contrarian results in Table 2 shows significant long-term contrarian LL-LW profits for most $J=36$ to 48 months and most $K$. For example, for the 3-year (36-month) formation period and 6-month holding period $(K=6)$ case, the difference between the average monthly returns of the LL portfolio is $1.06 \%$ per month $(t$-stat 2.22$)$, which is statistically significant. In sum, the holding period returns in Table 2 give indication of a long-term return contrarian effect at the firm level.

Table 3 reports the average monthly holding period returns for the buying, selling, and buying-selling portfolios of the BE/ME strategy when applied to the sample of 40 Qatar firms. Columns 2 through 6 list the equal-weighted average monthly returns in percentages for the $K$-month holding periods $(K=1,3,6,9$ and 12-month).

The result in Table 3 indicates clearly that the value strategy produces significant profits for all $K$ holding periods. For instance, the BE/ME strategy earns a significant 1.51 per month ( $t$-stat 3.08). In general, comparing the results in Table 3 with those in Table 2 demonstrates that the BE/ME strategy profits are always higher than the 
profits of the long-term contrarian strategy. However, the two alternative measures of value still generate high levels of profitability.

Table 3. Profitability of BM at Qatar firms

\begin{tabular}{llllll}
\hline \multicolumn{7}{c}{ Holding period Returns } \\
\hline Portfolio & K=1 & K=3 & K=6 & K=9 & K=12 \\
\hline HV & $2.38 \%$ & $1.66 \%$ & $1.64 \%$ & $1.02 \%$ & $1.05 \%$ \\
& $(2.13)$ & $(1.65)$ & $(1.99)$ & $(1.41)$ & $(1.44)$ \\
LV & $0.42 \%$ & $0.02 \%$ & $0.12 \%$ & $-0.29 \%$ & $-0.13 \%$ \\
& $(0.44)$ & $(0.03)$ & $(0.15)$ & $(-0.36)$ & $(-0.16)$ \\
HV-LV & $1.95 \%$ & $1.64 \%$ & $1.51 \%$ & $1.31 \%$ & $1.18 \%$ \\
& $(3.2)$ & $(2.69)$ & $(3.08)$ & $(2.66)$ & $(2.38)$ \\
\hline
\end{tabular}

Table 3 provides the average monthly holding period returns in percentages of the buying, selling, and buying-selling portfolios for the BE/ME strategy applies to 40 Qatar firms. At the beginning of each month $t$ from January 2005 to April 2014, the 40 firms are ranked based on their BE/ME, and are assigned to one of four portfolios. The high BE/ME equal-weighted portfolios (HV) comprises of the $25 \%$ of firms with the highest values, while the low BE/ME comprises of the $25 \%$ of firms with the lowest values. HV-LV refers to the buying the fourth portfolio and selling first portfolio. All reported returns are equally weighted. The strategy LL-LW longs the long-term loser portfolio and shorts the long-term winner portfolio to be held for $K=1,3,6$, 9 , or 12 months. The $t$-statistics are based on the Newey and West (1987) adjustment for autocorrelation up to lag 11 .

\subsection{Post Holding Results}

As noted earlier, either long-term return contrarian strategy or BE/ME strategy provide significant contrarian profits. In this section, Table 4 and 5 presents evidence of the value strategies for 40 Qatar firms. Because these value effects may continue for longer than the holding periods used in the long-term contrarian strategy, it is useful to recognize how long the contrarian last. This part uses annual event-time returns to investigate how long such contrarian of past performances continues. The last four columns of Table 4 and 5 report event-time returns (the average annual returns for each portfolio for the four and 4-year after the formation date, respectively), together with the associated t-statistic based on the Newey and West (1987) autocorrelation adjustment up to lag 11 .

Table 4. Profitability of long-term return contrarian at Qatar firms

\begin{tabular}{|c|c|c|c|c|c|}
\hline \multirow[b]{2}{*}{$\mathbf{J}$} & \multicolumn{5}{|c|}{ Annual Event Time Returns } \\
\hline & Portfolio & Year 1 & Year 2 & Year 3 & Year 4 \\
\hline \multirow[t]{6}{*}{36} & LL & $12.04 \%$ & $25.33 \%$ & $25.84 \%$ & $20.93 \%$ \\
\hline & & (1.28) & $(6.17)$ & $(3.85)$ & $(3.05)$ \\
\hline & LW & $-0.74 \%$ & $13.20 \%$ & $16.60 \%$ & $9.68 \%$ \\
\hline & & $(-0.1)$ & (3.12) & $(2.97)$ & $(3.47)$ \\
\hline & LL-LW & $12.78 \%$ & $12.13 \%$ & $9.23 \%$ & $11.25 \%$ \\
\hline & & $(4.58)$ & (3.19) & $(1.24)$ & $(1.29)$ \\
\hline \multirow[t]{6}{*}{48} & LL & $24.42 \%$ & $25.91 \%$ & $15.57 \%$ & $9.87 \%$ \\
\hline & & (7.48) & $(4.38)$ & $(2.36)$ & (3.64) \\
\hline & LW & $12.64 \%$ & $13.30 \%$ & $13.31 \%$ & $10.10 \%$ \\
\hline & & $(4.1)$ & $(2.71)$ & $(6.08)$ & $(2.12)$ \\
\hline & LL-LW & $11.78 \%$ & $12.60 \%$ & $2.25 \%$ & $-0.23 \%$ \\
\hline & & $(3.52)$ & (1.92) & $(0.31)$ & $(-0.04)$ \\
\hline \multirow[t]{6}{*}{60} & LL & $23.27 \%$ & $22.40 \%$ & $10.37 \%$ & $10.84 \%$ \\
\hline & & $(5.81)$ & (4.59) & $(3.53)$ & $(2.39)$ \\
\hline & LW & $11.98 \%$ & $8.89 \%$ & $9.22 \%$ & $26.02 \%$ \\
\hline & & $(2.53)$ & $(5.66)$ & $(3.06)$ & (11.87) \\
\hline & LL-LW & $11.29 \%$ & $13.51 \%$ & $1.15 \%$ & $-15.18 \%$ \\
\hline & & $(2.18)$ & (3.4) & $(0.22)$ & $(-6.12)$ \\
\hline
\end{tabular}

This table provides the annual event time returns in percentages of the selling, buying, and arbitrage portfolios of 
the long-term reversal strategy for 40 Qatar firms. Portfolios are constructed as follows: At the beginning of each month $\mathrm{t}$, the 40 firms are sorted derived from their past $J$-month formation period returns for $J=36$, 48, and 60 -month. The long-run loser equal-weighted portfolio (LL) comprises of the $25 \%$ of portfolios with the lowest returns, and the long-term winner equal weighted portfolio (LW) comprises of the $25 \%$ of portfolios with the highest returns. The strategy LL-LW buys the long-run loser portfolio and sells the long-run winner portfolio to be held for the first four years after the portfolio formation date. The $t$-statistics depends on the Newey and West (1987) adjustment for autocorrelation up to lag 11.

For the long-term return reversal strategies in Table 4, the first three years have positive LL-LW returns. These positive returns refers to prices continue to reverse throughout the first three years of the post-formation period. Clearly, the first two years provide statistically significant contrarian profits at the $5 \%$ level.

Consider first the event-time returns for the zero-cost BE/ME portfolios (HV-LV) in Table 5. The result shows that BE/ME strategy in Table 5 provides statistically significant profits in both first and fourth years. While the second year is weakly significant and the third year is not significant, they are all positive.

Overall, the findings in Table 4 and 5 propose that the two alternative measures of value either long-term return contrarian strategy or BE/ME strategy provide large levels of portability. Clearly, when comparing the results in Table 5 with those in Table 4 demonstrates that the BE/ME strategy profits are always larger than the profits of the long-term return contrarian strategy. This result is consistent with the previous result achieved by Table 2 and 3.

The post formation behaviour of the long-term return contrarian and BE/ME strategies' profits is also illustrated in Figure 1. Figure 1 depicts the post-formation cumulative returns of the long-term contrarian strategy (LL-LW), and the BE/ME strategy (HV-LV) employing non-overlapping portfolios $(\mathrm{K}=1)$ for the 60 -month after the end of the formation period. For two strategies depicted, it is evident that the contrarians of long term past performances show no signs of slowing down by the end of the first 60 post-formation months.

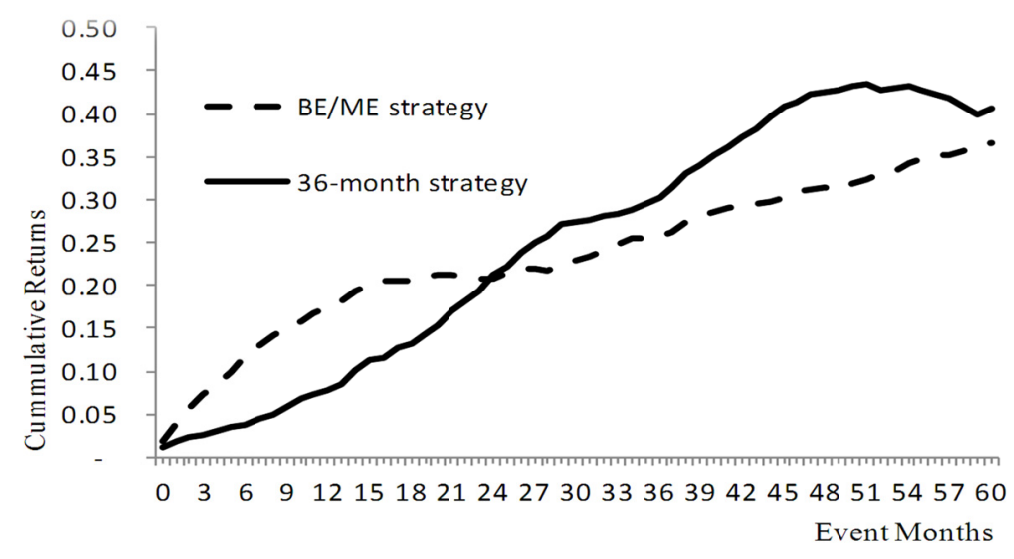

Figure 1. Cumulative return of value strategies

This graph presents the cumulative returns of the long-term return reversal portfolio LL-LW (with $J=36$ months) and BE/ME strategy HV-LV using non-overlapping portfolio $(K=1)$ for the 60 months after the end of the formation period. 
Table 5. Profitability of BE/ME at Qatar firms

\begin{tabular}{lllll}
\hline \multicolumn{5}{c}{ Annual Event Time Returns } \\
\hline Portfolio & Year 1 & Year 2 & Year 3 & Year 4 \\
\hline HV & $43.12 \%$ & $41.13 \%$ & $51.51 \%$ & $54.67 \%$ \\
& $(1.65)$ & $(1.24)$ & $(1.3)$ & $(1.28)$ \\
LV & $24.66 \%$ & $26.53 \%$ & $32.90 \%$ & $42.61 \%$ \\
& $(0.91)$ & $(1.03)$ & $(1.27)$ & $(1.06)$ \\
HV-LV & $18.45 \%$ & $14.60 \%$ & $18.62 \%$ & $12.06 \%$ \\
& $(4.06)$ & $(1.88)$ & $(1.28)$ & $(2.53)$ \\
\hline
\end{tabular}

This table provides annual event time returns in percentages of the long, short, and long-short portfolios for the BE/ME strategy applies to 40 Qatar firms. At the beginning of each month $t$ from January 2005 to April 2014, the 40 firms are ranked based on their $\mathrm{BE} / \mathrm{ME}$, and are assigned to one of four portfolios. The high $\mathrm{BE} / \mathrm{ME}$ equal-weighted portfolios (HV) comprises of the $25 \%$ of firms with the highest values, while the low BE/ME comprises of the $25 \%$ of firms with the lowest values. HV-LV refers to the buying the fourth portfolio and selling first portfolio. All reported returns are equally weighted. The strategy LL-LW buys the long-run loser portfolio and sells the long-run winner portfolio to be held for the first four years following the portfolio formation date The $t$-statistics are based on the Newey and West (1987) correction for autocorrelation up to lag 11.

\subsection{Risk Adjustment}

To investigate whether the profits of the value strategies should be measured a reward for bearing risk, the profits of the value strategies are risk corrected employing the Fama-French three-factor model. The three-factor model includes a market factor, a small minus big and a value minus growth factors as follows:

$$
R_{p t}=\alpha_{p}+\beta_{p} R_{m t}+s_{p} S M B_{t}+h_{p} H M L_{t}+\varepsilon_{p t}
$$

Where the dependent variable $R_{p t}$ is the monthly return of portfolio $p$ at time. For the independent variables, $R_{m t}$ denotes the Qatar MSCI index's monthly return for month $t$, while $S M B_{t}$ and $H M L_{t}$ are the monthly size and book-to-market factors at time $t$, respectively.

Table 6. Risk-Adjusted long-term return contrarian and BE/ME profits

\begin{tabular}{|c|c|c|c|c|c|}
\hline \multicolumn{6}{|c|}{ Three-Factor Model } \\
\hline & $\alpha$ & $\beta$ & $\mathbf{s}$ & $\mathbf{h}$ & Adj $R^{2}$ \\
\hline \multicolumn{6}{|c|}{ Panel A: Long-Term Return Contrarian (36/6) } \\
\hline \multirow[t]{2}{*}{ LL } & 0.011 & 0.306 & 0.198 & 0.374 & $15.6 \%$ \\
\hline & $(1.91)$ & $(1.6)$ & $(1.33)$ & $(2.21)$ & \\
\hline \multirow[t]{2}{*}{ LW } & 0.006 & 0.226 & -0.028 & 0.168 & $-0.1 \%$ \\
\hline & $(0.8)$ & $(0.88)$ & $(-0.18)$ & $(0.74)$ & \\
\hline \multirow[t]{2}{*}{ LL-LW } & 0.005 & 0.08 & 0.226 & 0.206 & $18.0 \%$ \\
\hline & $(1.24)$ & $(0.71)$ & (3) & $(1.63)$ & \\
\hline \multicolumn{6}{|c|}{ Panel B: BE/ME strategy } \\
\hline \multirow[t]{2}{*}{$\mathbf{L V}$} & 0.002 & 0.380 & 0.052 & -0.248 & $20.6 \%$ \\
\hline & $(0.46)$ & $(1.94)$ & $(0.43)$ & $(-1.51)$ & \\
\hline \multirow[t]{2}{*}{ HV } & 0.002 & 0.442 & 0.078 & 0.665 & $33.9 \%$ \\
\hline & $(0.28)$ & (2) & $(0.6)$ & $(3.65)$ & \\
\hline \multirow[t]{2}{*}{ HV-LV } & -0.001 & 0.062 & 0.026 & 0.913 & $93.7 \%$ \\
\hline & $(-0.64)$ & $(1.55)$ & $(1.06)$ & $(20.21)$ & \\
\hline
\end{tabular}


Table 6 provides the three-factor regression findings for the monthly returns of the long-term return contrarian portfolios for $J=36$ and $K=6$ in Panel A, the BE/ME portfolios for $K=6$ in Panel B. These portfolios are described in Tables 2 and 3 . The three-factor regression model is as follows:

$$
R_{p t}=\alpha_{p}+\beta_{p} R_{m t}+s_{p} \mathrm{SMB}_{\mathrm{t}}+h_{p} \mathrm{HML}_{\mathrm{t}}+\varepsilon_{p t}
$$

Where $R_{p t}$ is the portfolio's return, $R_{m t}$ is the return on the market, $\mathrm{SMB}_{\mathrm{t}}$ is the Fama-French size factor, and $\mathrm{HML}_{\mathrm{t}}$ is the Fama-French book-to-market factor. The $t$-statistics presented in parentheses are corrected for heteroskedasticity using White's (1980) test.

The monthly returns for the Fama-French factors covering the full sample period from January 2005 to April 2014 are calculated by the difference between the first and fifth. The coefficients $\beta_{p}, s_{p}$ and $h_{p}$ are the regression loadings corresponding to the factors of the model, while the intercept $\alpha_{p}$ (or simply alpha) represents the risk-adjusted abnormal returns of the portfolios over the estimation period. An alpha that is significantly different from zero is evidence of abnormal profits. Regression coefficient $t$-values are corrected for heteroskedasticity using White's (1980) test.

Table 6 presents the estimated regression coefficients and the associated $t$-values for the long, short and long-short portfolios for the two value strategies with six-month holding periods $(K=6)$. The alphas of the three value zero-cost portfolios (LL-LW and HV-LV, respectively) in Panel A and B are small $(0.005 \%$ and $-0.001 \%$ per month) and insignificant ( $t$-stat 1.24 and 0.64 , respectively). Clearly, the results show that there is an inter-firm value effect that can be explained by the Fama-French three-factor model.

\section{Summary and Conclusions}

This study has examined whether there is a value effect across Qatar firms. Two measures have been used to test inter-firm value effect. Long-term contrarian of firm returns using contrarian strategies with long formation period lengths (36, 48 and 60 months) and book-to-market ratio. This paper answers this question in the affirmative. The result of this study finds a significant inter-firm value effect that is highly consistent across two measures of value. This finding shows that it is possible to predict the future performance of firms that have extreme ratios of in past long-term returns or have experienced extremes ratios of book-to-market equity.

The returns of the firm-level value strategies can be explained by the Fama-French three-factor model and this finding confirms the Fama and French's (1996) findings. This means that the value effect at the industry level is driving from changing fundamentals for the firms.

these results reveal that it is potential to forecast the future performance of stocks that have experienced extreme in past long-run returns and extreme ratios of book-to-market equity. such predictability in firms returns has vital implications for researchers, investors and fund managers. For fund manager, they should consider whether the stocks that they invest either based on book-to-market equity ratio or in long-term contrarian return. for instance, should they remain invested in stocks in firms which the extreme book-to-market ratio or long-term contrarian strategies of this paper propose will underperform in the present years.

\section{References}

Asness, C. S., Moskowitz, T. J., \& Pedersen, L. H. (2013). Value and momentum everywhere. The Journal of Finance, 68(3), 929-985. http://dx.doi.org/10.1111/jofi.12021

Brennan, M. J., Chordia, T., \& Subrahmanyam, A. (1998). Alternative factor specifications, security characteristics, and the cross-section of expected stock returns. Journal of Financial Economics, 49(3), 345-373. http://dx.doi.org/10.1016/S0304-405X(98)00028-2

Chen, H. J. (2011). Firm life expectancy and the heterogeneity of the book-to-market effect. Journal of Financial Economics, 100(2), 402-423. http://dx.doi.org/10.1016/j.jfineco.2010.12.007

Chou, P. H., Ho, P. H., \& Ko, K. C. (2012). Do industries matter in explaining stock returns and asset-pricing $\begin{array}{llll}\text { anomalies? Journal of Banking \& } & \text { Finance, } & 36(2), & 355-370 .\end{array}$ http://dx.doi.org/10.1016/j.jbankfin.2011.07.016

Chou, P. H., Ko, K. C., \& Lin, S. J. (2010). Do relative leverage and relative distress really explain size and book-to-market anomalies? Journal of Financial Markets, 13(1), 77-100. 
http://dx.doi.org/10.1016/j.finmar.2009.07.007

DeBondt, W. F. M., \& Thaler, R. (1985). Does the stock market overreact? Journal of Finance, 40(3), 793-805. http://dx.doi.org/10.1111/j.1540-6261.1985.tb05004.x

Dempsey, M. (2010). The book-to-market equity ratio as a proxy for risk: Evidence from Australian markets. Australian Journal of Management, 35(1), 7-21.

Fama, E. F., \& French, K. R. (1992). The cross-section of expected stock returns. Journal of Finance, 427-465. http://dx.doi.org/10.1111/j.1540-6261.1992.tb04398.x

Fama, E. F., \& French, K. R. (1993). Common risk factors in the returns on stocks and bonds. Journal of Financial Economics, 33(1), 3-56. http://dx.doi.org/10.1016/0304-405X(93)90023-5

Fama, E. F., \& French, K. R. (1996). Multifactor explanations of asset pricing anomalies. The Journal of Finance, 51(1), 55-84.

Fama, E., \& French, K. (2008). Dissecting anomalies. The Journal of Finance, 63(4), 1653-1678. http://dx.doi.org/10.1177/0312896209351451

Ferguson, M. F., \& Shockley, R. L. (2003). Equilibrium “anomalies”. The Journal of Finance, 58(6), 2549-2580. http://dx.doi.org/10.1046/j.1540-6261.2003.00615.x

Kassimatis, K. (2008). Size, book to market and momentum effects in the Australian stock market. Australian Journal of Management, 33(1), 145. http://dx.doi.org/10.1177/031289620803300108

Lakonishok, J., Shleifer, A., \& Vishny, R. W. (1994). Contrarian investment, extrapolation, and risk. The Journal of Finance, 49(5), 1541-1578. http://dx.doi.org/10.1111/j.1540-6261.1994.tb04772.x

Newey, W. K. A., \& West, K. D. (1987). A simple, positive semi-definite, heteroskedasticity and autocorrelation consistent covariance matrix. Econometrica: Journal of the Econometric Society, 703-708. http://dx.doi.org/10.2307/2526578

Peterkort, R. F., \& Nielsen, J. F. (2005). Is the book-to-market ratio a measure of risk? Journal of Financial Research, 28(4), 487-502.

Simlai, P. (2009). Stock returns, size, and book-to-market equity. Studies in Economics and Finance, 26(3), 198-212. http://dx.doi.org/10.1108/10867370910974026

Stattman, D. (1980). Book values and stock returns. The Chicago MBA: A Journal of Selected Papers, 4, 25-45.

White, H. (1980). A heteroskedasticity-consistent covariance matrix estimator and a direct test for heteroskedasticity. Econometrica: Journal of the Econometric Society, 48, 817-838. http://dx.doi.org/10.2307/1912934

Zhang, C. (2008). Decomposed Fama-French Factors for the Size and Book-to-market Effects. Working Paper.

\section{Copyrights}

Copyright for this article is retained by the author(s), with first publication rights granted to the journal.

This is an open-access article distributed under the terms and conditions of the Creative Commons Attribution license (http://creativecommons.org/licenses/by/3.0/). 